2015-06

The Relational Geographies of Policing and Security

\author{
Yarwood, Richard
}

http://hdl.handle.net/10026.1/3970

10.1111/gec3.12216

Geography Compass

Wiley

All content in PEARL is protected by copyright law. Author manuscripts are made available in accordance with publisher policies. Please cite only the published version using the details provided on the item record or document. In the absence of an open licence (e.g. Creative Commons), permissions for further reuse of content should be sought from the publisher or author. 
The Relational Geographies of Policing and Security

\begin{tabular}{|r|l|}
\hline Journal: & Geography Compass \\
\hline Manuscript ID: & Draft \\
\hline Wiley - Manuscript type: & Article \\
\hline Keywords: & $\begin{array}{l}\text { Social }<\text { Compass Sections, city }<\text { Key Topics, crime }<\text { Key Topics, Social } \\
\text { Geography < Geography < Subjects, citizenship < Key Topics }\end{array}$ \\
\hline \multicolumn{2}{|l}{} \\
\hline
\end{tabular}

SCHOLARONE ${ }^{m}$

Manuscripts 


\section{The Relational Geographies of Policing and Security}

It is estimated that in a typical weekend 25,000 people visit Union Street, Plymouth's night club strip. These thousands are policed by just sixteen police officers each night. While these numbers seem small, the police are just one part of 'Operation Expound', a multi-agency operation to maintain public order and safety in Plymouth's night time economy (NTE). As well as the state police, door-staff, military police, special constables, publicans, Closed Circuit Television (CCTV) operators, Street Pastors, paramedics, local businesses and licensing agencies are all enrolled into a policing network that helps to shape the space of the night time economy.

This approach is not unique to the NTE and many places are being shaped by a range of public, private and voluntary agencies that have responsibility for the policing of daily life. While existing work has studied the composition, effectiveness and appropriateness of these alliances (Yarwood 2007, Cook 2010), we argue that greater attention is needed on the spatial practices of the agencies enrolled into these partnerships. These not only reflect how space is viewed and regulated, but also help to shape different places and the social relations in them.

To begin doing this, we consider the spatial practices of security and policing. Although the terms are often used interchangeably, we argue that there are subtle but significant differences between the two (Table 1). Policing is most commonly associated with the 'maintenance of order, the control of disorder, the prevention of crime and the detection of offenders' (Rawlings 2008, p. 47) whereas security is concerned with protection of people, places or objects from threats (Graham and Gregory 2009, Zedner 2009). There are also important spatial differences between the two ideas: while security is concerned with territory, policing relates to place. 
Table 1 summarises these apparent differences and is used as a jumping off point for this paper.

\begin{tabular}{|c|c|c|}
\hline Social Impact & Policing & Security \\
\hline Practices & $\begin{array}{c}\text { Shaping attitudes and } \\
\text { values }\end{array}$ & $\begin{array}{c}\text { Conserving values and } \\
\text { attitudes }\end{array}$ \\
\hline Types of space & $\begin{array}{c}\text { Varies from proactive to } \\
\text { reactive }\end{array}$ & Exclusion \\
\hline Spatiality & Public & Private and mass-public \\
\hline Accountability & Places & Territories \\
\hline
\end{tabular}

Table 1: Differences between policing and security practices

We should point out at this stage that we do not associate particular agencies exclusively with one or other of these practices. The state police, for example, have important security functions and, increasingly, private and voluntary agencies also deliver forms of policing. Instead, we recognise security and policing as practices that are deployed by different agencies in relation to each other and the spaces they attempt to control. The following sections of the paper discuss these practices in turn and how they shape and define space. In the final section, we return to the example of the night-time economy and suggest how practices of security and policing can be understood as a relational policing network.

Security, Territory, Exclusion

Security, as Lucia Zedner (2009, p.9) notes, is a 'promiscuous concept' that has been widely but inconsistently deployed across a range of spaces and contexts. At a state or global level, discourses of 'national security' have influenced the development of external foreign policy, internal homeland security, urban architecture and the defence of sites against perceived global threats (Adey 2009, Anderson and Adey 2012, Martin 2010, Philo 2012). Our focus in this paper, though, 
is at the domestic level where ideas of security have been used to counter crimes such as theft or assault (Berg 2010, Wakefield 2008).

Security has often been taken to mean 'freedom from imagined or real danger in present or future' (Graham and Gregory 2009, p.672) but this is impossible to achieve for 'absolute security implies a condition of being without threat, which, even if it could be achieved today, always remains liable to negation by new threats tomorrow' (Zedner 2009). A key assumption, therefore, of many security practices is that anyone or anything is a potential threat. Thus, everyone exiting a shop is required to pass through electronic barriers as they may have stolen goods concealed on their bodies; all employees are required to carry identity cards to prove their legitimacy; all entrants to a night club are searched for weapons; all passengers at airports are subject to bodily surveillance; and all emails are scanned as they can carry viruses.

These forms of security focus on 'preventing the worse' (Johnston 2001) through the creation of literal and metaphorical barriers to keep out people, ideas and things that are seen to threaten the security of a space (Young 1999, Herbert \& Brown 2006, Loader 2006, Zedner 2009). Young (1999) argues that these practices have led to an 'exclusive society' that aims to 'hold at bay and exclude' those regarded as threatening security, be it someone who will not consume in a shopping centre or a person who appears to disrupt the ideal of suburbia. Security practices construct particular social groups as being more likely than others to threaten particular spaces (Raco 2003). While some may be allowed through barriers others will be 'banished' from the spaces they protect (Herbert and Beckett 2010, Wakefield 2008). These spatial practices are most clearly seen in the regulation of highly 
secure private and semi-public spaces such as gated communities or shopping malls where access is conditional on behaving in ways that are compliant with and support the owners' purposes (Atkinson 2003, Shearing \& Wood 2003).

Yet, increasingly, these principles are also being applied to public space. In Cape Town, for example, City Improvement Districts (CIDs) require businesses to pay a levy that, in turn, is used to fund private security patrols in public space (Paasche et al. 2013). These are mainly concerned with excluding so-called 'undesirables', such as the homeless, sex-workers, and urban poor, from defined territories that are given over to consumption. Equally, many state police forces have also adopted zero-tolerance policies that implement Wilson and Kelling's (1982) 'broken windows' thesis that supposes physical disorder contributes crime (Fyfe 2010, Fyfe et al 2006, Herbert \& Brown 2006). Zero-tolerance practices are a form of security that target what or who is deemed to cause fear, including aggressive panhandling, squeegee cleaners, street prostitution, boombox cars, public drunkenness, reckless bicyclists, and graffiti' (Giuliani and Bratton 1994, p.5) as well as addicts, rowdy teenagers, prostitutes, loiterers, the mentally disturbed and strangers, all of whom that Wilson and Kelling (1982) summarise as 'undesirable'.

Security operates in private and public space and is practised by public and state agencies. In all cases, however, security relies on defining and protecting a particular territory. Security practices do not seek to use places to modify behaviour but, rather, to use space in a territorial way to exclude behaviour that is threatening to its hegemonic, imagined values. The definition, communication and enforcement of particular bounded spaces are the ways in which security is spatially empowered 
(Sack 1983). Security thus appears to hold a symbiotic relationship with territory: it helps to define a territory that, in turn, defines the extent of its power.

Indeed, the purpose of securing a particular territory is to produce space that is different from those around it. As Zedner (2009, p.61) observes a complex geography of security is emerging that encompasses different "patchworks', 'quilts', 'bubbles', 'corridors', 'mosaics', 'webs', 'networks' and 'nodes” of secure spaces that extend across different urban spaces in different ways. In a study of Maputo, Mozambique, Paasche and Sidaway (2010) reveal how urban space is divided into a patchwork of public, private and 'ad hoc' actors that have reduced the city to a series of micro-security-enclaves that reflect and enforce existing inequalities in development and power. Shearing and Wood (2003, p.406) argue that a form of nodal governance has emerging that is controlled by private actors in specific spaces: 'people now live within a world full of crisscrossing group memberships that simultaneously operate across and through multiple governmental domains'. Security contributes to a form of stratified mobility that grants access to urban spaces for some but, at the same time, denies it to others.

These forms of security, which rely dominantly on exclusion or banishment, have what Herbert and Beckett (2010, p.240) describe as a 'paper-thin' understanding of place. They fail to appreciate the processes that lead to people becoming vulnerable and show little concern at where they move to when they are banished. Pushing people out of one place into another does not provide a solution to deep-seated social problems that extend beyond the territories in question. While some neighbours and premises benefit from additional private and voluntary policing, others become places where threats are banished to, exacerbating social difference 
(Herbert 2010). Such understandings of place fail to appreciate the nature of complex social relations that are found within particular places and contribute to social exclusion (Cresswell 1996, Herbert 2008, Mitchell 2005).

Treating neighbourhoods or city centres as territories to be cleansed and secured is short-sighted, ineffective and socially divisive. In short, a greater understanding of place is needed to provide a more appropriate response to these issues. Arguably the concept of policing is, or at least should be, centred on place as opposed to territory. The following section re-focuses attention on policing and, in particular, how different conceptualisations of place are important to this.

Policing and Place

Policing is a far broader concept than security and encompasses a wider range of practices (Yarwood 2007) that include:

organised forms of order maintenance, peacekeeping, rule of law enforcement, crime investigation and prevention and other forms of investigation and associated informationbrokering - which may involve a conscious exercise of coercive power - undertaken by individuals or organisations, where such activities are viewed by them and/or others as a central or key defining part of their purpose (Jones and Newburn, 2002, p.19)

Practices and discourses of policing vary widely within and between places, reflecting different systems and efforts to maintain the interests of state, capital and class. Thus, policing can range from violent suppression through to forms of community actions that attempt to empower people to police their own localities (Bowling \& Foster 2002, Paasche 2013a). Despite this variety, the practice of policing differs from security in three ways. 
First, policing concerned with the aftermath of a crime, rather than simply preventing it from happening. Thus, judicial-policing regimes will take action against those who have offended and, in principal at least, take measures, including imprisonment, with the aim encouraging offenders to conduct their own conduct in ways that are acceptable to wider society (Foucault 1977).

Second, policing uses place to achieve acceptable forms of conduct. Placebased policing relies on a range of agencies working together to resolve issues inside a particular locality (Cook 2010, Henry \& Smith 2007, Mackenzie \& Henry 2009); it is proactive in nature, attempting to prevent crimes before they occur. Thus, policing agencies may liaise with schools or youth groups to provide activities for young people that, in turn, aim to prevent anti-social behaviour (Brown 2013). In principle at least, these forms of partnership are, or should be, accountable to all sections of the population and, in some cases minority groups, such as gay people, have been able to gain a foothold in the way that their localities and needs are policed (McGhee 2003).

In these instances, policing aims to work within a space to control and modify behaviour inside it. In contrast, security practices control space by excluding threats from it. Policing is an attempt to produce social control through the creation of systems or surveillance coupled with the threat of sanctions' (Reiner 1994) or, after Foucault (1977), a set of practices aimed at encouraging self-conduct that is deemed acceptable to wider society. Thus, policing encompasses a wider range of practices than simply aiming to exclude (DeVerteuil et al. (2009)). In a study of Skid Row, Los Angeles Stuart demonstrates how the police, working with other agencies, have attempted to reform rather than banish the homeless and concludes that "policing 
practices re-imagine homeless people as moral beings that, beyond their poor choices, behaviours and lifestyles, are essentially 'like us' (2013, p.15).

This is not to suggest that place-based policing is a panacea for the ills of the post-justice city. Far from it. The 'trapdoor of community', as Herbert (2005) puts it, means that many people unable or unwilling to work in formal partnership fall past the opportunities they offer. Communities that are unable or unwilling to govern themselves are less likely to benefit from community policing. As Desforges et al (2005, p.441) argue people 'are judged to have succeeded or failed as citizens of a place-based community, with repercussions for the further treatment of that locality by the state' or, put simply, community has come to be viewed as the cause and solution of social ills (Herbert-Cheshire 2000). This can lead to a neglect of places outside the boundaries of a community, so that the displacement of crime becomes some other community's concern. Yet, for all its faults, these forms of policing represent an attempt to work with different agencies, inside a place, to shape rather than conserve attitudes and values.

Finally, then, while policing replicates dominant power relations and can be a way of coercing the populace, it reflects, or should reflect, broader ideals of citizenship. Garland (2001) argues that the responsibility for crime control must be shared amongst the government, non-state actors and organisations Thus, those who are policed have rights and duties, including the right to involve themselves in policing practices. State police forces, in democracies at least, are accountable to their populace through various political-judicial measures. Indeed, Elected Police and Crime Commissioners, for example, have recently been introduced for every police force in England and Wales with the intention of improving the accountability of 
police forces to the communities they serve. Neighbourhood Watch and other forms of community policing, for example, reflect principles of 'active citizenship' and the duties of citizens to involve themselves in policing (Fyfe, 1995a). While the police use surveillance, they are also subject to it to a greater extent than many other agencies (Mawby, 2002). The notion that policing is driven by citizenship is normative and, as many studies have shown, class and spatial differences impact on this ideal (Herbert, 2006). Nevertheless, the principle is an important one that distinguishes policing from the security paradigm.

\section{Policing and Security: A Relational Approach}

In the sections above, we have argued that policing and security constitute two subtly different but important sets of practices. We have not associated particular agencies with particular practices as, increasingly, private, voluntary and state agencies have all performed various forms of policing and security. So, rather than a focus on particular agencies, we argue that geographers should instead focus on how particular practices are used create and control different types of spaces. To do this, we advocate a relational approach.

Relational geographies recognise how networks and flows of ideas, people and technologies have challenged 'an older topography in which territoriality was dominant' (Amin 2004, p. 6). Rather than being 'fixed', space is reproduced through consensual and contested processes, as Murdoch (2006, p.20) suggests 'while multiple sets of relations exist, there is likely to be some competition between these relations over the composition of particular spaces and places'. Applied to the geographies of crime, relational approaches allow place, territory, policing and 
security to be considered relatively to and fluidly with each other. We propose three ways that this should be taken forward.

First, there is a need to examine how different policing and security practices shape and define urban spaces. For example, how do practices of policing and security define space and shape social outcomes within them? For example, if practices of security are producing exclusive enclaves in urban areas, how are spaces outside these policed or secured? What are the consequences for people living in or moving through differently secured/policed areas?

Second, it should be recognised that although the practices of policing and security appear to manifest themselves in particular places or territories, they are themselves products of much wider social and political networks. The spaces of security and policing are more than spatial containers but, instead, are the consequence of on-going governance activities and control mechanisms (Elden 2010). The securing of a territory relies on networks of actors that extend well beyond the physical space of that territory and deploy various technologies and databases to secure it (Adey 2009; Paasche 2013a). As Paasche (2013b) and Stuart (2013) demonstrate, agencies not normally associated with policing, such as social workers or charities, have been enrolled into networks that police homeless people and may contribute to their exclusion from some urban spaces.

Finally, policing and security represent forms of bio-politics (Foucault 2007) that aim to reconfigure the composition of a population. This includes the control of the population to ensure that it behaves according to formal and informal rules of the particular territory. Although legislation constitutes and delineates territories or places as 'different' from surrounding urban space, the practices within these places 
enact these ideas and allow them to become manifest in these spaces (Paasche, 2012). The practices of security and policing demonstrate that territories are dependent on law and techniques used to enforce it; it is political process in which space is 'owned, distributed, mapped, calculated, bordered and controlled' (Elden 2010: 810). The legal space and the property rights of the mall, gated community or Business Improvement District might act as a demarcation and reference point for security activities but it is security's bio-political governing activities that create the territory and its boundaries. Policing and security are thus the spatial outcomes of a particular social order (Herbert and Brown 2006).

In the final section, we return to Union Street to consider how its space and spaces are shaped by different forms of policing and security.

\section{Return to Union Street}

The night time economy of Union Street is controlled by a number of state, private and voluntary agencies who use space in particular ways. Certainly, territorial forms of security are important. The most obvious example are door staff or 'bouncers' who are charged with maintaining order in the private spaces of nightclubs or pubs. Their modus-operandi is to allow or prevent entry to premises (Monaghan 2002). This may be on the grounds that a person or persons may cause trouble (perhaps because they have drunk too much) or simply that they do not meet the dress codes or image of the bar. Their work illustrates the principles of security, in that barriers to the space or territory of premises are used to filter out potential threats to the social order insider it. If this order is disrupted by people inside the club, they are simply ejected into the street where the responsibility of the bouncers 
ends. They may, as the example shows above, be tracked by CCTV and, if necessary, be subject to police action.

In the public spaces of the NTE, the police are the dominant agency. As Herbert $(1996,1997)$ demonstrates, police follow a normative order that structures their response to particular situations in particular spaces. Although ostensively concerned with maintaining law and order, this kind of policing reflects a moral order that accepts the consumption of alcohol to excess as long as the law is not broken. As well as formal practices of policing and security, those on a night out are selfpoliced through informal codes of behaviour, gestures and actions that may be variously seen as aggressive, welcoming and ambiguous (Amin 2012, Jayne et al., 2010, Thrift 2005) and, as such, can include, exclude or modify behaviour that may clash with formal ideas of policing.

Drawing on specific legislation and licensing laws (Hadfield 2006), the whole territory of the NTE can be used as a territory to exclude those viewed as trouble makers. For example, those who may have been ejected from a night club may be issued with a Penalty Notice Disorder (PND) by police officers that requires them to leave the NTE area on pain of being arrested. The aim is to exclude in order to prevent crime. Persistent offenders can be banished via a court-issued 'Drinking Banning Order', banning them from licensed premises for two years. Intelligence gathered from outside the NTE may also be used to target known or potential offenders.

Yet some forms of behaviour, such as rowdy groups, are tolerated in the spaces of the night-time economy that would not be tolerated elsewhere (say a residential area) as they contribute to the generation of capital through the night-time 
economy. One CCTV operator commented that a group of twenty rowdy young men outside a pub 'are fine' and unlikely to cause trouble. Often, the police are reluctant to intervene unless a crime has been committed (Jayne et al. 2010). Yet other types of behaviour, such as begging, are prosecuted as these activities are deemed to be detrimental to the image projected by the NTE. This underlines that policing is concerned with maintaining a hegemonic code of behaviour. More recently, Christian Street Pastors have started to provide voluntary care for people on a night out that they consider are in need of help but do not warrant attention from the emergency services (e.g. minor first aid and the distribution of suitable footwear) (Middleton \& Yarwood 2014). This perhaps represents policing in its broadest sense as StreetPastors attempt not only to provide practical help but to change behaviour and the moral codes of revellers.

\section{Conclusion}

This paper has argued that there subtle but significant differences between policing and security. Although Table 1 suggested a binary, we acknowledge a blurring between the two, especially as increasingly many agencies practice both security and policing. Yet, it is still important to distinguish between the two as there they have significant consequences for urban space (and beyond). We therefore contest that policing and security might be considered as a series of relational 'encounters' that shape space and social relations in it. Union Street provides one example but more detailed work is needed on other places and territories.

We also posit that thinking in this way has important applied value. In common with other commentators (Herbert \& Brown 2006, Young 1999), we share a concern that policing and security has become too focused on exclusionary 
practices. It is important to wrench practices of policing and security away from the notions tightly bounded spatial areas, be they the premises of a shopping mall or the bounded community of a residential district. Thinking in more relational ways will help to connect different places and people, rather than simply attempting to exclude those who do not fit. The challenge for geographers is not only to rethink the spatialities of policing and security but to promote research agendas that will encourage practitioners to do the same.

References

Adey P. (2009). Facing airport security: affect, biopolitics, and the pre-emptive securitisation of the mobile body. Environment and Planning D: Society and Space 27, pp.274-295.

Amin A. (2004). Regions unbound: towards a new politics of place. Geografiska Annaler: Series B, Human Geography 86, pp. 33-44.

Amin A. (2012). Land of strangers, Bristol: Polity Press.

Anderson B and Adey P. (2012). Governing events and life: 'emergency' in UK civil contingencies. Political Geography 31, pp. 24-33.

Atkinson, R. (2003). Domestication by cappuccino or a revenge on urban space? Control and empowerment in the management of public spaces. Urban Studies 40, pp.1829-1843.

Berg, J. (2010). Seeing like private security: evolving mentalities of public space protection in South Africa. Criminology and Criminal Justice 10, pp. 287-301.

Bowling, B and Foster J. (2002). Policing and the police. In: Maguire M, Morgan M and Reiner R (eds) The Oxford Handbook of criminology (third edition). Third Edition ed. Oxford: Oxford University Press, pp. 980-1033.

Brown, DM. (2013). Young people, anti-social behaviour and public space: the role of community wardens in policing the 'ASBO generation'. Urban Studies 50, pp. 538-555.

Cook, I. (2010). Policing partnerships and profits: the operations of business improvement districts and town centre management schemes in England. Urban Geography 31, pp. 453-478.

Cresswell, T. (1996). In place/out of place: geography, ideology and transgression Minneapolis: University of Minnesota Press

Desforges, L., Jones, R. and Woods, M. (2005) New geographies of citizenship, Citizenship Studies 9, pp. $439-451$

DeVerteuil, G., May, J., and von Mahs, J. (2009). Complexity not collapse: recasting the geographies of homelessness in a 'punitive' age. Progress in Human Geography 33, pp. 646-666. 
Elden, S. (2010). Land, terrain, territory. Progress in Human Geography 34, pp.799817.

Foucault, M. (1977). Discipline and punish: the birth of the prison, New York: Pantheon Books.

Foucault, M. (2007) Security, territory, population. Basingstoke: Palgrave Macmillan

Fyfe, N. (2010). Crime and the re-moralisation of city spaces. In: Smith, S., Pain, R., Mardsen, S., et al. (eds) Sage handbook of social geographies. London: Sage, pp. 474-487.

Fyfe, N., Bannister J. and Kearns, A. (2006). (In)civility and the city. Urban Studies 43, pp. 853-861.

Garland, D. (2001). The culture of control, Oxford: Oxford University Press.

Giuliani, R. and Bratton, W. (1994). Police strategy No. 5: reclaiming the public spaces of New York, New York: Office of the Mayor.

Graham, S and Gregory, D. (2009). Security. In: Gregory D, Johnston R, Pratt G and Watts, G. (eds) The dictionary of human geography 5th edition. Oxford: WileyBlackwell, pp. 672-673.

Hadfield, P. (2006). Bar wars: contesting the night in contemporary british cities, Oxford: Oxford University Press.

Henry, H. and Smith, D. (2007). Transformations of policing Farnham: Ashgate.

Herbert, S. (1996). The normative ordering of police territoriality: making and marking space with the Los Angeles Police Department. Annals of the Association of American Geographers 86, pp. 567-582.

Herbert, S. (1997). Territoriality and the police. Professional Geographer 49, pp. 8694.

Herbert, S. (2006). Citizens, cops and power: recognizing the limits of community, Chicago: University of Chicago Press.

Herbert, S. (2008). Contemporary geographies of exclusion I: traversing Skid Row. Progress in Human Geography 32, pp. 659-666.

Herbert, S. (2010). Urban outcasts: a comparative sociology of advanced marginality. Urban Geography 31, pp. 153-157.

Herbert, S. and Beckett, K. (2010). 'This is home for us': questioning banishment from the ground up. Social and Cultural Geography 11, pp. 231-245.

Herbert, S and Brown, E. (2006). Conceptions of space and crime in the punitive neoliberal city. Antipode 38, pp. 755-777.

Jayne, M., Valentine, G. and Holloway, S. (2010). Emotional, embodied and affective geographies of alcohol, drinking and drunkenness. Transactions of the Institute of British Geographers 35, pp. 540-554.

Johnston, L. (2001). Crime, fear and civil policing. Urban Studies 38, pp. 959-976.

Jones, T. and Newburn, T. (2002). Private security and public policing, Oxford: Oxford University Press.

Mackenzie, S. and Henry, A. (2009). Community policing: a review of the evidence, Edinburgh: Scottish Government.

Martin, L. (2010). Bombs, bodies, and biopolitics: securitizing the subject at the airport security checkpoint. Social and Cultural Geography 11, pp. 17-34.

McGhee, D. (2003). Joined-up government, 'community safety' and lesbian, gay, bisexual and transgender 'active citizens'. Critical Social Policy 23, pp. 345374.

McGhee, D. (2004). Beyond toleration: privacy, citizenship and sexual minorities in England and Wales. British Journal of Sociology 55, pp. 357-375. 
Middleton, J., and Yarwood, R. (2013). Christians out here? Encountering StreetPastors in the post-secular spaces of the UK's night-time economy Urban Studies, forthcoming

Mitchell, D. (2005). The SUV model of citizenship: floating bubbles, buffer zones, and the rise of the "purely atomic" individual. Political Geography 24, pp. 77100.

Monaghan, L. (2002). Regulating 'unruly' bodies: work tasks, conflict and violence in Britain's night-time economy. British Journal of Sociology 53, pp. 403-429.

Murdoch, J. (2006). Post-structuralist geography: a guide to relational space, London: Thousand Oaks.

Paasche, T. (2012). Creating parallel public spaces through private governments: a South African case study. South African Geographical Journal 94, pp. 46-59.

Paasche, T. (2013a). Coded police territories: "detective software' investigates. Area 45, pp. 314-320.

Paasche, T. (2013b). 'The softer side of security': The role of social development in Cape Town's policing network. Geoforum 45, pp. 261-267.

Paasche, T. and Sidaway, J. (2010). Transecting security and space in Maputo. Environment and Planning A 42, pp. 1555-1576.

Paasche, T; Yarwood, R and Sidaway, J (2014). Territorial tactics: the socio-spatial significance of private policing strategies in Cape Town Urban Studies 51, pp. 1559-1575.

Philo, C. (2012). Security of geography/geography of security. Transactions of the Institute of British Geographers 37, pp. 1-7.

Raco, M. (2003). Remaking place and securitising space: urban regeneration and the strategies, tactics and practices of policing in the UK. Urban Studies 40, pp. 1869-1887.

Rawlings, G. (2008). Policing before the police. In: Newburn T (ed) Handbook of policing. Cullompton: Willan Publishing, p.. 41-65.

Reiner, R. (1994). Police and the policing. In: Maguire, M., Morgan, R. and Reiner, R. (eds) Oxford handbook of criminology, second edition. Oxford: Oxford University Press, pp. 997-1050.

Sack, R. (1983). Human territoriality - a theory. Annals of the Association of American Geographers 73, pp. 55-74.

Shearing, C. and Wood, J. (2003). Nodal governance, democracy, and the new 'denizens'. Journal of Law and Society 30,pp. 400-419.

Stuart F. (2013). From 'rabble management' to 'recovery management': policing homelessness in marginal urban space. Urban Studies 51, pp. 1909-1925

Thrift, N. (2005). But malice aforethought: cities and the natural history of hatred. Transactions of the Institute of British Geographers 30, pp. 133-150.

Wakefield, A. (2008). Private policing: a view from the mall. Public Administration 86, .pp 659-678.

Wilson, J. and Kelling, G. (1982). Broken windows: The police and neighborhood safety. Atlantic Quarterly, pp. 29-38.

Yarwood, R. (2007). The geographies of policing. Progress in Human Geography 31, pp. 447-466.

Young, J. (1999). The exclusive society: social exclusion, crime and difference in late modernity. London: Sage.

Zedner, L. (2009). Security, London: Routledge. 